\title{
UPAYA PENINGKATAN KEMAMPUAN KERJA SAMA DAN PRESTASI BELAJAR SISWA KELAS XI IPA 1 PADA MATERI HIDROLISIS MELALUI MODEL PEMBELAJARAN TEAMS ASSISTED INDIVIDUALIZATION (TAI) MENGGUNAKAN MEDIA MODUL DI SMA NEGERI 1 NGEMPLAK BOYOLALI TAHUN AJARAN 2016/2017
}

\author{
Afifah Naufalia Rahmadheanti, Bakti Mulyani", dan Suryadi Budi Utomo \\ Program Studi Pendidikan Kimia, FKIP,Universitas Sebelas Maret, Surakarta, Indonesia
}

*Keperluan Korespondensi, telp: 081227611216, email: baktimulyani@gmail.com

\begin{abstract}
ABSTRAK
Penelitian ini bertujuan untuk meningkatkan kerja sama dan prestasi belajar siswa melalui model pembelajaran kooperatif Teams Assisted Individualization (TAl) menggunakan media modul pada materi Hidrolisis. Penelitian ini merupakan Penelitian Tindakan Kelas (PTK) yang terdiri dari dua siklus dengan tiap siklus terdiri dari perencanaan, pelaksanaan, pengamatan dan refleksi. Subjek penelitian adalah siswa kelas XI IPA 1 SMA Negeri 1 Ngemplak Boyolali Tahun Ajaran 2016/2017. Data diperoleh dari observasi, angket, tes objektif dan wawancara. Validitas penelitian menggunakan triangulasi data. Hasil penelitian menunjukkan bahwa penerapan model pembelajaran Teams Assisted Individualization (TAI) menggunakan media modul pada materi Hidrolisis dapat meningkatkan kerja sama dan prestasi belajar siswa. Hal ini dapat dilihat dari penelitian menunjukkan bahwa capaian persentase kerja sama siswa sebesar $86 \%$ pada siklus I dan $94 \%$ pada siklus II. Aspek afektif siswa pada siklus I sebesar $89 \%$ dan pada siklus II sebesar $92 \%$. Aspek kognitif siswa siklus I sebesar $53 \%$, pada siklus II sebesar $78 \%$, serta prestasi belajar pada aspek psikomotor sebesar $87 \%$.
\end{abstract}

Kata kunci: Teams Assisted Individualization (TAI), modul, kerja sama siswa, prestasi belajar, hidrolisis.

\section{PENDAHULUAN}

Salah satu tujuan nasional bangsa Indonesia yang telah dijelaskan dalam Undang-Undang Dasar Negara Republik Indonesia tahun 1945 dalam alinea 4 yaitu mencerdaskan kehidupan bangsa. Menurut Pasal 1 Undang-Undang nomor 20 tahun 2003 tentang Sistem Pendidikan Nasional, dijelaskan bahwa pendidikan merupakan usaha sadar dan terencana untuk mewujudkan suasana belajar dan proses pembelajaran agar peserta didik secara aktif mengembangkan potensi dirinya untuk memiliki kekuatan spiritual keagamaan, pengendalian diri, kepribadian, kecerdasan, akhlak mulia serta keterampilan yang diperlukan dirinya, masyarakat, bangsa dan negara. Upaya peningkatan mutu pendidikan tidak terlepas dari kualitas kegiatan belajar mengajar di kelas. Pemilihan metode pembelajaran yang tepat menjadi salah satu faktor yang menentukan keberhasilan kegiatan belajar mengajar. Metode pembelajaran adalah cara yang digunakan guru untuk menyampaikan materi kepada peserta didik karena penyampaian tersebut berlangsung dalam interaksi edukatif. Metode pembelajaran dapat diartikan sebagai cara yang digunakan guru dalam berinteraksi dengan siswa pada saat berlangsungnya pengajaran. Dengan demikian, metode pembelajaran merupakan alat untuk menciptakan proses belajar mengajar [1].

Kimia merupakan salah satu mata pelajaran wajib di Sekolah Menengah Atas (SMA). Kimia merupakan salah satu cabang penting dalam ilmu pengetahuan dan hal ini memungkinkan bagi para 
siswa untuk memahami apa yang terjadi di sekitar mereka, karena pada dasarnya topik kimia terkait dengan struktur materi serta kimia merupakan subjek yang sulit bagi para siswa karena disisi lain kimia juga mengandung konsep-konsep yang abstrak [2].

Observasi dilakukan di SMA Negeri 1 Ngemplak Boyolali. Data didapatkan melalui beberapa sumber. Salah satunya adalah hasil ulangan materi Hidrolisis Garam kelas XI pada tahun ajaran 2015/2016 yang ditunjukkan pada Tabel 1.

Tabel 1. Persentase kelulusan materi hidrolisis kelas XI SMA Negeri 1 Ngemplak Boyolali tahun ajaran 2015/2016

\begin{tabular}{ccc}
\hline Kelas & $\begin{array}{c}\text { Jumlah } \\
\text { Siswa }\end{array}$ & $\begin{array}{c}\text { Persentase } \\
\text { Ketuntasan }\end{array}$ \\
\hline IPA 1 & 32 & $23,07 \%$ \\
IPA 2 & 32 & $60,00 \%$ \\
IPA 3 & 32 & $45,45 \%$ \\
IPA 4 & 31 & $47,61 \%$ \\
\hline
\end{tabular}

(Sumber: Nilai Ulangan Harian Hidrolisis Kelas XI IPA Tahun Ajaran 2015/2016).

Berdasarkan Tabel 1, dapat disimpulkan bahwa persentase ketuntasan materi hidrolisis paling rendah adalah pada kelas XI IPA 1, dengan persentase ketuntasan sebesar $23,07 \%$.

Persentase ketuntasan materi kimia kelas XI semester 1 SMA Negeri Ngemplak Boyolali pada tahun ajaran 2016/2017 dapat ditunjukkan dalam Tabel 2.

Tabel 2. Persentase ketuntasan materi kimia kelas XI IPA SMA Negeri 1 Ngemplak Boyolali pada Ulangan Akhir Semester 1 tahun ajaran 2016/2017

\begin{tabular}{ccc}
\hline Kelas & $\begin{array}{c}\text { Jumlah } \\
\text { Siswa }\end{array}$ & $\begin{array}{c}\text { Persentase } \\
\text { Ketuntasan }\end{array}$ \\
\hline IPA 1 & 32 & $6,67 \%$ \\
IPA 2 & 32 & $10,00 \%$ \\
IPA 3 & 32 & $6,67 \%$ \\
IPA 4 & 31 & $14,81 \%$ \\
\hline
\end{tabular}

(Sumber: Nilai Ulangan Akhir Semester 1 kelas XI IPA Tahun Ajaran 2016/2017)
Dari Tabel 2, dapat disimpulkan dari rata-rata nilai UAS Kimia semester 1 , kelas XI IPA 1 dan kelas XI IPA 3 memiliki rata-rata nilai terendah dibanding kelas yang lainnya yaitu persentase ketuntasan nilai UAS kimianya adalah sebesar $6,67 \%$. Peneliti mengambil kelas XI IPA 1 sebagai kelas yang akan dilaksanakan penelitian karena memiliki persentase ketuntasan terendah diantara kelas lain dan terkait dengan izin penelitian yang diberikan oleh pihak sekolah.

Observasi lain melalui pengamatan secara langsung, guru masih menggunakan metode ceramah. Kegiatan siswa hanya mendengarkan guru saat menjelaskan materi dan mencatat materi yang disampaikan. Penggunaan metode ceramah ini mengakibatkan siswa menjadi pasif dan menyebabkan kegiatan pembelajaran berjalan kurang efektif serta interaksi belajar di dalam kelas tersebut tergolong rendah khususnya interaksi antar sesama siswa seperti misalnya kerja sama tim, memecahkan masalah bersama, menanggapi pendapat satu sama lain dan sebagainya. Rutinitas belajar yang demikian yang memungkinkan menjadi penyebab kurang maksimalnya prestasi belajar siswa. Hal ini menjadi perhatian bagi peneliti. Dalam penelitian yang sudah dilakukan oleh Rahmawati menyebutkan bahwa metode pembelajaran yang bersifat konvensional sebagai penyebab rendahnya prestasi belajar siswa [3].

Salah satu upaya untuk menyelesaikan masalah yang ada di kelas dan meningkatkan kualitas belajar siswa SMA Negeri 1 Ngemplak Boyolali adalah melalui Penelitian Tindakan Kelas (PTK), karena prinsip dari PTK itu sendiri adalah memperbaiki dan meningkatkan kualitas pembelajaran. Dalam penelitian ini menggunakan model pembelajaran kooperatif tipe Teams Assisted Individualization (TAl). Metode ini mengupayakan agar siswa terlibat aktif dalam kegiatan belajar mengajar dan terjadi interaksi antar sesama sehingga siswa saling memotivasi untuk meningkatkan kemampuannya. Model pembelajaran kooperatif tipe TAI merupakan 
metode yang efektif untuk meningkatkan prestasi belajar siswa dibidang sains. Penerapan model pembelajaran ini membuat prestasi siswa lebih tinggi dibanding dengan metode konvensional. Model pembelajaran tipe TAl dapat digunakan untuk mengajarkan materi sains dimana siswa dapat dipercaya untuk mengambil alih proses belajar dalam kelompoknya serta dapat meningkatkan karakter ilmiah siswa serta meningkatkan kemampuan mengingat siswa [4]. Model pembelajaran kooperatif tipe TAl dapat diartikan sebagai kelompok yang dibantu secara individual atau kelompok dimana ada seorang asisten yang membantu secara individual di dalam kelompok tersebut [5].

Media pembelajaran yang digunakan pada proses belajar mengajar hanya berpedoman pada LKS. Beberapa siswa memiliki buku paket, tetapi buku yang dimiliki tiap siswa berbeda satu sama lain sehingga pemahaman siswa terhadap materi terkadang tidak selaras karena info yang didapat berbeda satu sama lain. Hal ini juga memungkinkan menghambat siswa dalam menguasai materi yang sekiranya membutuhkan pemahaman mendasar.

Media pembelajaran dapat digunakan sebagai pendukung dari model pembelajaran. Media pembelajaran dapat didefinisikan sebagai sesuatu yang mengantarkan pesan pembelajaran antara si pemberi pesan ke penerima pesan [6]. Dalam penelitian ini menggunakan media modul Hidrolisis. Modul merupakan buku panduan bagi siswa dalam kegiatan pembelajaran yang memuat materi, kegiatan penyelidikan berdasarkan konsep, kegiatan sains, informasi dan contoh penerapan sains dalam kehidupan sehari-hari [7]. Media modul dapat dijadikan pedoman berisikan ringkasan dengan alur konsep materi yang jelas, rumus-rumus yang terkait serta latihan-latihan soal pendalaman materi. Dengan demikian guru lebih bisa memantau mengenai pemahaman siswa dan siswa berkemampuan kurang dapat lebih terbimbing.

Dari uraian di atas, penulis bermaksud melakukan Penelitian Tindakan Kelas tentang upaya peningkatan kemampuan kerja sama dan prestasi belajar siswa melalui model pembelajaran kooperatif Teams Assisted Individualization (TAI) dengan menggunakan media modul pada materi hidrolisis di kelas XI IPA 1 SMA Negeri 1 Ngemplak Boyolali tahun ajaran 2016/2017.

\section{METODE PENELITIAN}

Penelitian ini merupakan Penelitian Tindakan Kelas (PTK) yang terdiri dari dua siklus dimana pada tiap siklus terdapat empat tahap yaitu perencanaan, tindakan, pengamatan dan refleksi. Subjek dari penelitian ini adalah siswasiswi kelas XI IPA 1 SMA Negeri 1 Ngemplak Boyolali Tahun Ajaran 2016/2017.

Data dalam penelitian meliputi data informasi tentang keadaan siswa dari aspek kualitatif dan kuantitatif, dimana aspek kualitatif merupakan data catatan lapangan pelaksanaan pembelajaran yang berpedoman pada lembar pengamatan dan hasil angket yang menggambarkan proses kegiatan belajar mengajar di kelas. Sedangkan aspek kuantitatif adalah hasil observasi dan hasil evaluasi siswa setelah mengikuti pembelajaran hidrolisis menggunakan media modul. Sumber data pada penelitian ini meliputi guru, siswa, dan peristiwa atau perilaku siswa selama pembelajaran serta arsip dari hasil tes dalam siklus I dan siklus II.

Pada penelitian ini menggunakan teknik triangulasi data. Teknik triangulasi data merupakan teknik pemeriksaan keabsahan data yang memanfaatkan sesuatu yang lain dari luar data itu untuk keperluan pengecekan atau sebagai pembanding terhadap data yang didapatkan [8]. Teknik triangulasi penelitian ini dilakukan dengan pengumpulan data melalui observasi, angket dan wawancara.

Instrumen pembelajaran meliputi silabus dan Rencana Pelaksanaan Pembelajaran (RPP), lembar observasi KBM dan Instrumen penilaian, meliputi aspek afektif, kognitif, kerja sama dan psikomotor. Sebelum digunakan dalam penelitian, instrumen divalidasi oleh dua panelis dan diuji cobakan terlebih dahulu 
pada kelas yang telah menerima materi hidrolisis, salah satunya adalah kelas XI IPA 4 SMA Negeri 1 Ngemplak Boyolali Tahun Ajaran 2016/2017.

\section{HASIL DAN PEMBAHASAN}

Berdasarkan data observasi dan wawancara yang dilakukan pada bulan April 2017, menunjukkan bahwa proses belajar mengajar masih berpusat pada guru atau bersifat teacher center. Menurut arsip nilai-nilai sebelumnya, diketahui bahwa materi hidrolisis merupakan materi yang memiliki ratarata nilai terendah. Dengan pembelajaran yang berpusat pada guru, siswa menjadi pasif dalam prosesnya. Padahal keaktifan siswa dan pemahaman siswa terhadap konsep-konsep materi merupakan kunci keberhasilan proses belajar yang dapat dilihat dari perolehan prestasi belajar siswa dalam kegiatan pembelajaran.

Salah satu indikator yang dapat meningkatkan prestasi belajar siswa adalah kerja sama. Siswa tentunya senang untuk belajar berkelompok karena disediakan sarana untuk berdiskusi guna menyelesaikan permasalahan yang mereka hadapi dan saling memotivasi untuk lebih baik satu sama lain. Melalui model pembelajaran $\mathrm{TAI}$, siswa dapat berkelompok untuk meningkatkan kerja sama. Siswa yang merasa malu untuk bertanya pada guru, atau berpendapat di kelas dapat memberanikan diri untuk bertanya pada asisten atau teman satu kelompoknya. Dengan kerja sama ini, maka kesulitan yang dihadapi seorang siswa akan teratasi sehingga prestasi belajar siswa akan meningkat.

\section{Siklus I}

\section{a. Perencanaan Tindakan}

Pada tahap perencanaan, peneliti bersama guru menyiapkan instrumen pembelajaran yang meliputi silabus, RPP, instrumen penelitian berupa instrumen penilaian belajar siswa pada aspek afektif atau sikap berupa tes angket dan lembar observasi, aspek kognitif atau pengetahuan berupa tes materi hidrolisis dan aspek psikomotor atau ketrerampilan berupa lembar observasi, serta media pembelajaran berupa modul hidrolisis. Pembelajaran dilaksanakan selama 10 jam pembelajaran meliputi 4 kali pertemuan. 3 kali pertemuan atau $8 \times 45$ menit untuk penyampaian materi dan 1 kali pertemuan atau $2 \times 45$ menit untuk melaksanakan evaluasi siklus I.

\section{b. Pelaksanaan Tindakan}

Proses pembelajaran TAI di kelas XI IPA 1, siswa dibagi menjadi 6 kelompok dengan tiap kelompok beranggotakan 6 orang termasuk 1 sebagai asisten.

Menurut sintak TAI, pada proses pembelajaran, guru hanya menyampaikan sebagian besar materi, kemudian siswa diberikan waktu untuk mempelajari dan mendalami materi secara berkelompok yang dipandu oleh asisten. Selanjutnya presentasi tiap kelompok dan tanya jawab untuk menyampaikan pendapat antar siswa apabila mereka memiliki persepsi yang berbeda. Selanjutnya dilaksanakan post test untuk mengetahui kemampuan individual dan yang terakhir adalah pemberian penghargaan bagi kelompok yang berprestasi. Dalam pertemuan pertama pembelajaran hidrolisis menggunakan model pembelajaran TAI, dilakukan demonstrasi tentang menentukan garam yang dapat terhidrolisis untuk mengetahui prestasi belajar siswa pada aspek psikomotor.

Di akhir siklus I dilaksanakan evaluasi akhir pembelajaran untuk mengukur prestasi belajar siswa pada aspek kognitif melalui tes materi hidrolisis, dan aspek afektif serta kerja sama siswa melalui tes angket.

\section{c. Hasil Tindakan Siklus I}

Tindakan pada siklus I menghasilkan penilaian terhadap prestasi belajar siswa pada aspek kerja sama, kognitif, afektif dan psikomotor siswa. Persentase hasil penilaian kerja sama siswa tiap kategori dapat dilihat pada Tabel 3. 
Tabel 3. Persentase Ketuntasan Aspek Kerja Sama Siklus I

\begin{tabular}{ccc}
\hline Kategori & $\begin{array}{c}\text { Jumlah } \\
\text { Siswa }\end{array}$ & $\begin{array}{c}\text { Persentase } \\
(\%)\end{array}$ \\
\hline Tinggi & 23 & 64 \\
Sedang & 8 & 22 \\
Rendah & 5 & 14 \\
\hline
\end{tabular}

Berdasarkan Tabel 3, dapat diketahui bahwa siswa yang kerja samanya tinggi sejumlah 23 siswa dengan persentase $64 \%$. Siswa yang berkategori sedang sebanyak 8 siwa dengan persentase $22 \%$ dan 5 siswa atau $14 \%$ yang kemampuan kerja samanya rendah.

Hasil belajar siswa pada aspek kognitif di kelas XI IPA 1, sejumlah 19 atau $53 \%$ siswa sudah mencapai batas tuntas sedangkan sejumlah 17 siswa arau $47 \%$ belum mencapai batas tuntas. Berdasarkan hasil yang diperoleh, dapat disimpulkan bahwa dalam siklus I, hasil belajar siswa pada aspek kognitif belum memenuhi target yang ditentukan yaitu sebesar $75 \%$. Terdapat lima indikator aspek kognitif pada siklus I, dari lima indikator terdapat tiga indikator yang belum tuntas yaitu indikator menentukan ciri-ciri garam yang terhidrolisis persentase ketuntasannya sebesar 56\%, indikator menentukan garam yang terhidrolisis melalui reaksi ionisasi persentase ketuntasannya sebesar $67 \%$, dan indikator menghitung $\mathrm{pH}$ larutan garam dengan persentase ketuntasannya sebesar $56 \%$.

Hasil belajar siswa siklus 1 pada aspek kognitif dapat dirangkum pada Tabel 4.

Tabel 4.Hasil Aspek Kognitif Siklus I

\begin{tabular}{ccc}
\hline Kategori & $\begin{array}{c}\text { Jumlah } \\
\text { Siswa }\end{array}$ & $\begin{array}{c}\text { Persentase } \\
(\%)\end{array}$ \\
\hline Tuntas & 19 & 53 \\
Tidak Tuntas & 17 & 47 \\
\hline
\end{tabular}

Hasil persentase penilaian aspek afektif tiap kategori ditunjukkan pada Gambar 1.

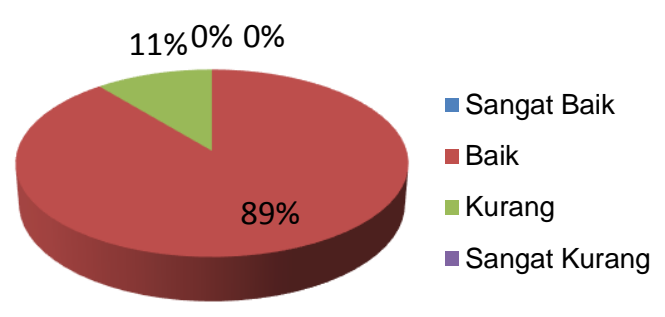

Gambar 1. Kategori Ketuntasan Aspek Kognitif Siklus I

Menurut Gambar 1, dapat diketahui bahwa 89\% siswa termasuk dalam kategori baik dan $11 \%$ siswa termasuk dalam kategori kurang. Secara umum, penilaian aspek afektif siswa pada siklus I sudah mencapai batas tuntas yaitu sebesar $89 \%$. Ketuntasan hasil belajar siswa kelas XI IPA 1 sudah mencapai batas tuntas yang sebelumnya ditetapkan yaitu sebesar $75 \%$.

Hasil penilaian aspek psikomotor siswa dapat dibuat kategori seperti Gambar 2.

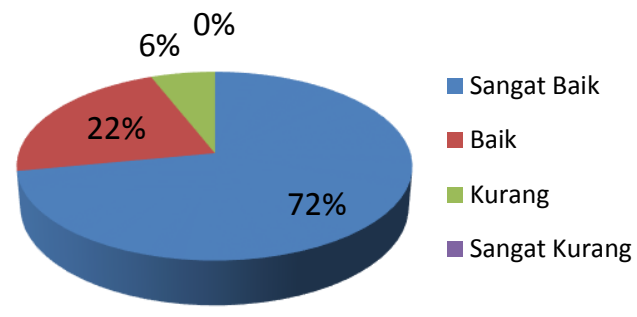

Gambar 2. Kategori Ketuntasan Aspek Psikomotor Siklus I

Berdasarkan Gambar 2, dapat diketahui bahwa sebesar $72 \%$ siswa termasuk dalam kategori sangat baik, $22 \%$ siswa termasuk dalam kategori baik, $6 \%$ siswa termasuk dalam kategori kurang dan tidak ada siswa yang termasuk dalam kategori sangat kurang. Dari hasil yang ada, maka dapat disimpulkan bahwa hasil belajar siswa kelas XI IPA 1 SMA Negeri 1 Ngemplak Boyolali tahun ajaran 2016/2017 pada aspek psikomotor sudah memenuhi batas tuntas yang telah ditetapkan.

Ketercapaian seluruh aspek pada siklus I dapat dirangkum pada Tabel 5. 
Tabel 5. Persentase Ketercapaian Siklus I Materi Hidrolisis Kelas XI IPA 1 SMA Negeri 1 Ngemplak Boyolali Tahun Ajaran 2016/2017.

\begin{tabular}{cccc}
\hline \multirow{2}{*}{ Aspek } & \multicolumn{2}{c}{ Siklus I (\%) } & \multirow{2}{*}{ Ket. } \\
\cline { 2 - 3 } & Target & Capaian & \\
\hline Kerja & 75 & 86 & $\sqrt{ }$ \\
Sama & 75 & 53 & - \\
Kognitif & 75 & 89 & $\sqrt{ }$ \\
Afektif & 75 & 94 & $\sqrt{ }$ \\
Psikomotor & 75 & 94 \\
\hline
\end{tabular}

Berdasarkan Tabel 5, dapat disimpulkan bahwa aspek kognitif siswa masih belum mencapai target. Sedangkan aspek afektif, kerja sama dan psikomotor telah mencapai target yang telah ditentukan.

\section{d. Refleksi}

Pada siklus I, masih terdapat aspek yang belum mencapai batas tuntas yaitu aspek kognitif, sehingga perlu dilaksanakan siklus II untuk memperbaiki dan meningkatkan hasil belajar siswa agar mencapai target yang sudah ditetapkan. Sedangkan untuk aspek kerja sama, afektif dan psikomotor sudah mencapai target yaitu $75 \%$. Seluruh aspek tetap diuji kembali di siklus II kecuali aspek psikomotor siswa. Tujuannya adalah untuk meningkatkan ketercapaian tiap indikator yang belum tuntas serta melihat kestabilan prestasi belajarnya terhadap materi Hidrolisis. Dalam tindakan siklus I, kelompokkelompok belajar yang dibentuk masih belum heterogen karena perbandingan siswa yang berkemampuan tinggi dan rendah masih belum rata. Oleh karena itu, pada siklus II dibentuk kelompok baru terdiri dari pemerataan siswa yang tuntas dan belum tentas berdasarkan hasil penilaian belajar pada siklus I.

\section{Siklus II}

\section{a. Perencanaan Tindakan}

Berdasarkan tahap refleksi yang sudah dilaksanakan di siklus I, maka dilaksanakan siklus II untuk meningkatkan hasil belajar siswa pada materi hidorlisis. Siklus II dilaksanakan dalam dua kali pertemuan. Pertemuan pertama selama 2 × 45 menit digunakan untuk membahas materi hidrolisis dengan penekanan pada indikator yang belum mencapai target. Pertemuan kedua selama 2 x 45 menit, digunakan untuk evaluasi pembelajaran siklus II.

\section{b. Pelaksanaan Tindakan}

Kegiatan pembelajaran pada siklus II yang dilakukan peneliti adalah membentuk kelompok baru secara heterogen dimana tiap kelompok terdiri atas siswa yang sudah mencapai batas KKM dan siswa yang belum mencapai batas KKM berdasarkan hasil evaluasi siklus I. Kemudian guru mengulang kembali indikator yang belum mencapai batas tuntas dan sesekali mengulas kembali indikator yang sudah mencapai batas tuntas. Selanjutnya siswa berdiskusi untuk memahami materi dibantu dengan asisten atau teman kelompok. Kemudian presentasi kelompok untuk saling bertukar pendapat, lalu post test guna mengukur pemahaman siswa terhadap materi yang sudah disampaikan. Diakhir pembelajaran, guru bersama siswa membuat kesimpulan materi serta pemberian penghargaan bagi kelompok yang berprestasi.

Pertemuan kedua adalah evaluasi akhir pembelajaran siklus II yang terdiri dari evaluasi aspek kognitif berupa tes materi hidrolisis dan evaluasi aspek afektif serta kerja sama berupa angket.

\section{c. Hasil Tindakan Siklus II}

Penilaian hasil belajar siswa pada aspek kerja sama pada siklus II yaitu melalui tes angket siswa. Berdasarkan analisis hasil belajar siswa pada aspek kerja sama pada siklus II, diperoleh persentase ketercapaian tiap kategori yang dapat dilihat pada Tabel 6 .

Tabel 6. Persentase Ketercapaian Hasil Belajar Siswa pada Aspek Kerja Sama Siklus II

\begin{tabular}{ccc}
\hline Kategori & $\begin{array}{c}\text { Jumlah } \\
\text { Siswa }\end{array}$ & $\begin{array}{c}\text { Persentase } \\
(\%)\end{array}$ \\
\hline Tinggi & 30 & 83 \\
Sedang & 4 & 11 \\
Rendah & 2 & 6 \\
\hline
\end{tabular}


Berdasarkan Tabel 6, dapat diketahui bahwa pada siklus II, siswa bekategori tinggi sebesar 83\% dan siswa yang berkategori sedang sebesar $11 \%$ dan rendah sebesar $6 \%$.

Untuk hasil belajar siswa pada aspek kognitif, dapat dilihat pada Tabel 7

Tabel 7. Hasil Aspek Kognitif Siklus II

\begin{tabular}{ccc}
\hline Kategori & $\begin{array}{c}\text { Jumlah } \\
\text { Siswa }\end{array}$ & $\begin{array}{c}\text { Persentase } \\
(\%)\end{array}$ \\
\hline Tuntas & 28 & 78 \\
Tidak & 8 & 22 \\
Tuntas & 8 & \\
\hline
\end{tabular}

Dari Tabel 7, dapat diketahui bahwa jumlah siswa yang sudah mecapai batas tuntas sebanyak 28 siswa dengan persentase sebesar $78 \%$ dimana artinya ketuntasan siswa pada aspek kognitif sudah mencapai target yang telah ditetapkan yaitu $75 \%$. Siswa berkategori tidak tuntas sebanyak 8 siswa dengan persentase $22 \%$.

Analisis hasil belajar siswa pada aspek afektif dapat dilihat pada Gambar 3.

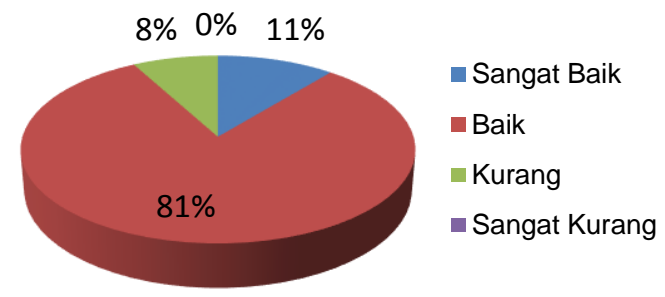

Gambar 3. Kategori Ketuntasan Aspek Afektif Siklus II

Berdasarkan Gambar 3, dapat diketahui bahwa hasil belajar siswa siklus II pada aspek afektif mengalami peningkatan dibanding pada siklus I. Sebesar $11 \%$ siswa kategori sangat baik, diimbangi dengan menurunnya siswa yang berkategori baik dengan persentase sebesar $81 \%$ dan penurunan siswa berkategori kurang dengan persentase sebesar $8 \%$ dan tidak ada siswa kategori sangat kurang atau sebesar $0 \%$.

Ketercapaian seluruh aspek pada siklus II dapat dirangkum pada Tabel. 8
Tabel 8. Persentase Ketercapaian Siklus II Materi Hidrolisis Kelas XI IPA 1 SMA Negeri 1 Ngemplak Boyolali Tahun Ajaran 2016/2017.

\begin{tabular}{lccl}
\hline \multirow{2}{*}{ Aspek } & \multicolumn{2}{c}{ Siklus II (\%) } & \multirow{2}{*}{ Kriteria } \\
\cline { 2 - 3 } & Target & Capaian & \\
\hline Kerja & 75 & 94 & Tercapai \\
Sama & 75 & 78 & Tercapai \\
Kognitif & 75 & 92 & Tercapai \\
Afektif & 75 & & \\
\hline
\end{tabular}

Dari Tabel 8, dapat diketahui bahwa pada siklus II, ketercapaian aspek kerja sama siswa sebesar $94 \%$, aspek kognitif siswa sebesar 78\%, dan aspek afektif siswa sebesar $92 \%$.

\section{d. Refleksi}

Berdasarkan hasil tindakan pada siklus II, hasil penilaian terhadap semua aspek meliputi aspek kerja sama, kognitif dan afektif siswa sudah memenuhi target pencapaian.

\section{Perbandingan Hasil Antarsiklus}

Hasil belajar siswa didapatkan dari observasi kerja sama dan sikap siswa pada tiap kegiatan pembelajaran, tes aspek kognitif dan angket afektif serta kerja sama siswa. Perbandingan ketercapaian kerja sama siswa dapat dilihat dari histogram yang disajikan pada Gambar 4.

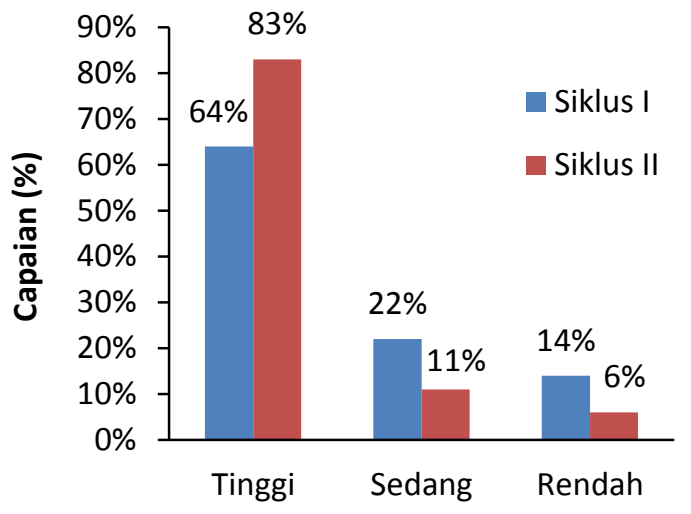

Gambar 4. Histogram Ketercapaian Kerja Sama Siswa pada Siklus I dan II

Dari Gambar 4, dapat diketahui bahwa persentase kerja sama siswa dengan kategori tinggi mengalami peningkatan dari siklus I ke siklus II. Hal tersebut seimbang dengan penurunan 
kategori sedang dan rendah dari siklus I ke siklus II. Dari data yang diperoleh, dapat disimpulkan bahwa kerja sama siswa kelas XI IPA 1 cukup baik dengan adanya peningkatan pencapaian jumlah siswa yang berkategori kerja samanya tinggi dari siklus I ke siklus II.

Prestasi belajar siswa terdiri dari aspek kognitif, afektif dan psikomotor. Berdasarkan hasil tes kognitif yang dilakukan pada siklus I dan II, ketuntasan aspek kognitif pada siklus I yaitu sebanyak 19 siswa dengan persentase $53 \%$ sudah mencapai batas tuntas dan sebanyak 17 siswa dengan persentase $47 \%$ masih belum mencapai batas tuntas. Sedangkan pada siklus II, sebanyak 28 siswa dengan persentase $78 \%$ sudah mencapai batas tuntas dan sebanyak 8 siswa dengan persentase $22 \%$ belum mencapai batas tuntas. Hal ini menunjukkan bahwa adanya peningkatan prestasi belajar siswa pada aspek kognitif dari siklus I ke siklus II. Perbandingan ketercapaian aspek kognitif siswa dapat dilihat dari histogram yang disajikan pada Gambar 5.

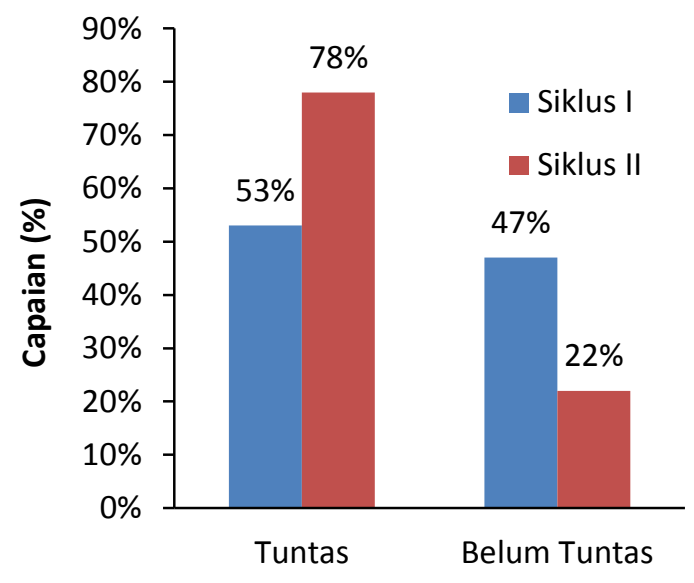

Gambar 5. Histogram Ketercapaian Aspek Kognitif Siswa pada Siklus I dan II.

Dari aspek kognitif siswa pada materi hidrolisis, terdapat lima indikator yang harus diuji. Dari hasil analisis pada siklus I dan siklus II didapatkan persentase ketercapaian masing-masing indikator kompetensinya. Perbandingan ketercapaian masing-masing indikator kompetensi materi hidrolisis dapat dilihat dari histogram pada Gambar 6 .

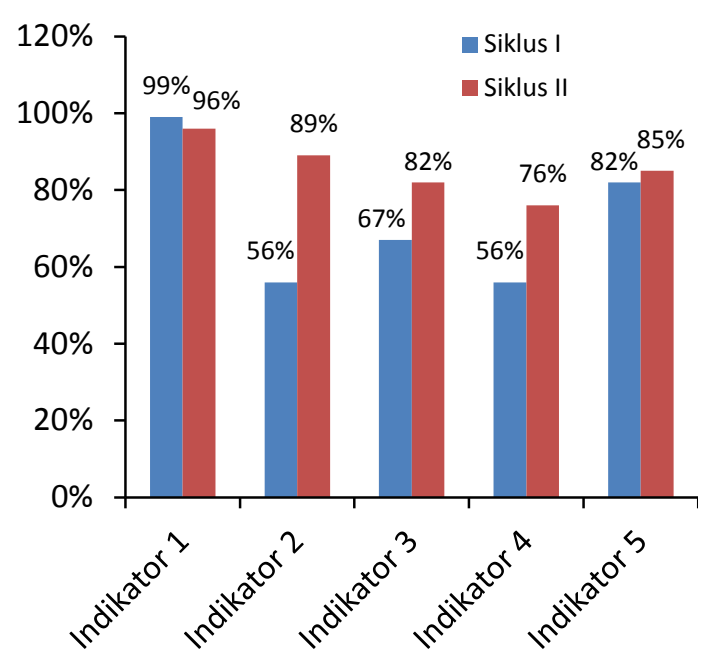

Gambar 6. Histogram Ketercapaian Tiap Indikator Kompetensi Aspek Kognitif Siklus I dan Siklus II.

Berdasarkan Gambar 6, sebagian besar tiap indikator kompetensi mengalami peningkatan dari siklus I ke siklus II. Indikator 1 mengalami penurunan 3\% yaitu dari $99 \%$ menjadi $96 \%$. Pada indikator 1 yaitu indikator menjelaskan pengertian hidrolisis secara umum dan khusus terdapat 2 soal, dan terdapat 2 siswa yang menjawab kurang tepat. Dimungkinkan siswa tersebut menjawab dengan metode guessing karena kurang mengerti jawaban dari pertanyaan yang diajukan.

Perbandingan ketercapaian aspek afektif siswa pada siklus I dan siklus II dapat dilihat dari histogram pada Gambar 7.

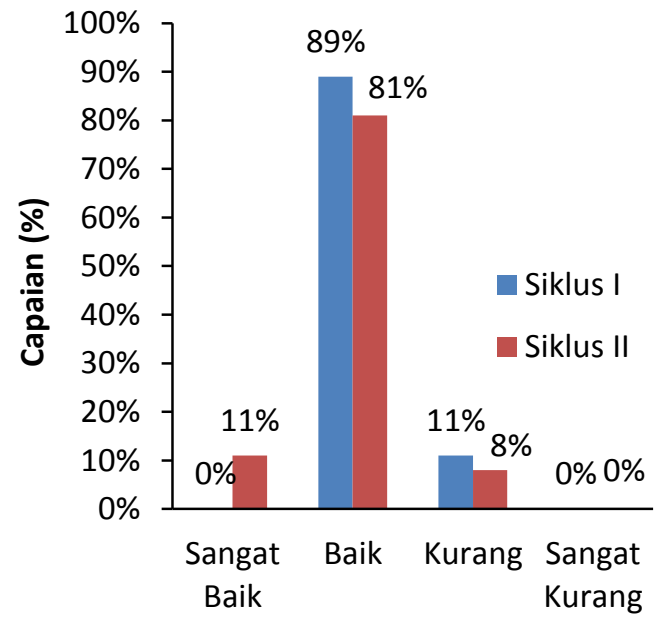

Gambar 7. Ketercapaian Aspek Afektif Siklus I dan Siklus II. 
Dari Gambar 7, dapat diketahui bahwa terjadi peningkatan persentase siswa yang berkategori sangat baik, dari $0 \%$ pada siklus I menjadi $11 \%$ yang diimbangi dengan penurunan siswa yang berkategori baik pada siklus I dengan persentase sebesar $89 \%$ menjadi $81 \%$ pada siklus II dan siswa berkategori kurang dengan persentase sebesar $11 \%$ pada siklus I menjadi $8 \%$ pada siklus II, sedangkan tidak ada siswa yang berkategori sangat kurang pada siklus I maupun siklus II.

Keberhasilan pembelajaran menggunakan model pembelajaran kooperatif Teams Assisted Individualization (TAl) pada penelitian ini relevan dengan penelitian yang dilakukan oleh Chaerunisa, menyatakan bahwa model pembelajaran kooperatif TAl dilengkapi dengan media peta konsep dapat meningkatkan kemampuan kerjasama dan prestasi belajar siswa pada materi termokimia [9]. Hasil penelitian ini juga relevan dengan penelitian yang dilakukan oleh Rositawati bahwa penggunaan model pembelajaran TAI berhasil untuk meningkatkan prestasi belajar siswa aspek afektif dan kognitif pada materi hukum dasar kimia dan konsep mol [10].

\section{KESIMPULAN}

Penerapan model pembelajaran kooperatif Teams Assited Individualization (TAl) menggunakan media modul dapat meningkatkan kerja sama dan prestasi belajar siswa pada materi Hidrolisis. Hal ini dapat dibuktikan dengan penilaian hasil belajar siswa pada siklus I dan II. Pada siklus I, ketercapaian persentase ketuntasan aspek kerja sama siswa sebesar $86 \%$ dan pada siklus II sebesar 94\%. Hasil belajar siswa aspek kognitif pada siklus I sebesar $53 \%$ dan meningkat menjadi $78 \%$ pada siklus II. Hasil belajar siswa aspek afektif pada siklus I sebesar $89 \%$ meningkat menjadi $92 \%$ pada siklus II. Sedangkan hasil belajar siswa aspek psikomotor pada siklus I sebesar 94\% dan tidak dilakukan perbaikan atau peningkatan hasil pada siklus II.

\section{UCAPAN TERIMA KASIH}

Penulis mengucapkan terima kasih kepada Bapak Drs. Sunarno, M.Pd selaku Kepala Sekolah SMA Negeri 1 Ngemplak Boyolali yang telah memberikan izin untuk melakukan penelitian serta Bapak Kristiyanto, S.Pd., selaku guru kimia di SMA Negeri 1 Ngemplak Boyolali yang telah memberikan kesempatan, kepercayaan, bimbingan, dan bantuan selama penelitian dilakukan.

\section{DAFTAR RUJUKAN}

[1] Salahudin, A. (2015). Penelitian Tindakan Kelas. Bandung: Penerbit Pustaka Setia.

[2] Sirhan, G. (2007).Journal of Turkish Science Education, 4(2), 1 - 19.

[3] Rahmawati, C.P., Ashadi., Utomo, S.B. (2015). JPK, 4(1), 1-9.

[4] Nneji, L. (2011). Nigerian Educational Research Journal, 23(4), 1-8.

[5] Slavin, R.E. (2011). Psikologi dan Pendidikan (Teori dan Praktik) (Edisi ke- 9, Jilid 2).Terj. Marianto Samosir. Jakarta: PT Indeks Permata Putri Media. (Buku asli diterbitkan 2009).

[6] Anitah, S. (2009). Media Pembelajaran. Surakarta: Panitia Sertifikasi Guru Rayon 13 FKIP UNS Surakarta.

[7] Trianto. (2009). Mendesain ModelModel Pembelajaran Inovatif Progresif. Jakarta: Kharisma Putra Utama.

[8] Moleong, L.J. (1996). Metodologi Penelitian Kualitatif. Bandung. PT Remaja Rosdakarya.

[9] Chaerunisa., Saputro, Sulistyo., Nugroho C.S, Agung (2016). JPK, 5(3), 1-9.

[10] Rositawati, H., Nurhayati, N.D., Redjeki, T. (2015). JPK, 4(4), 1-9. 